УДК 615.322:582.683.2].074:547.56]-047.37

DOI https://doi.org/10.11603/2312-0967.2020.4.11539

\title{
ДОСЛІДЖЕННЯ ФЕНОЛЬНИХ СПОЛУК РИЖІЮ ПОСІВНОГО (САMЕLINA SATIVA (L.) CRANTZ) ТА РИЖІЮ ДРІБНОПЛОДОГО (CAMELINA MICROCARPA ANDRZ.)
}

\author{
Т. О. Цикало, С. Д. Тржецинський \\ Запорізький державний медичний університет \\ tetyanatsykalo@ukr.net
}

ІНФОРМАЦІЯ

Надійшла до редакції / Received: 22.09.2020

Після доопрацювання / Revised: 28.10.2020

Прийнято до друку / Accepted: 29.10.2020

\section{Ключові слова:}

рижій посівний;

рижій дрібноплодий;

фрлавоноїди;

гідроксикоричні кислоти;

полісренольні сполуки;

тонкошарова хроматографрія;

високоефективна рідинна

хроматографрія.
АНОТАЦІЯ

Мета роботи. Дослідити склад френольних сполук у траві та насінні видів роду Camelina (L.) Crantz.

Матеріали іметоди. Длядослідженнявикористовувалитравутанасіннярижію посівного сорту Славутич і рижію дрібноплодого. Для досліджень готували водно-спиртові витяжки, як екстрагент використовували $70 \%$ етиловий спирт. Для попередньої оцінки якісного складу витяжок використовували якісні реакції та ТШХ-дослідження у системі розчинників н-бутанол - кислота оцтова льодяна - вода (4:1:2). Хроматограми переглядали у денному та УФсвітлі до і після обробки парами амоніаку. Визначення якісного складу та кількісного вмісту окремих фенольних сполук виконували методом ВЕРХ. Кількісне визначення загального вмісту фрлавоноїдів, гідроксикоричних кислот і поліфенолів виконували спектрофотометричним методом.

Результати й обговорення. В результаті ТШХ-дослідження встановлено, що у траві та насінні всіх зразків представників роду Camelina (L.) Crantz присутній рутин. В траві обох видів ідентифріковано хлорогенову кислоту. Методом BEPX підтверджено наявність даних сполук і встановлено, що вміст рутину вищий у насінні рижію дрібноплодого $(0,361 \pm 0,001) \%$, а хлорогенової кислоти - в траві рижію дрібноплодого $(0,279 \pm 0,004) \%$. у результаті спектрофотометричного визначення вмісту френольних сполук у сировині даних видів встановлено, що більший вміст фрлавоноїдів, похідних гідроксикоричних кислот та загальний вміст френольних сполук характерний для трави рижію посівного і складає $(1,17 \pm 0,08) \%,(1,47 \pm 0,03) \%$ i

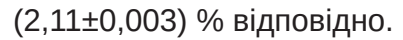

Висновки. Методом ТШХ ідентиорікували та методом ВEPX визначили кількісний вміст рутину та хлорогенової кислоти у траві та насінні рижію посівного (Camelina sativa (L.) Crantz) і рижію дрібноплодого (Camelina microcarpa Andrz.). Спектрофотометричним методом визначили загальну суму фрлавоноїдів, гідроксикоричних кислот та поліфенолів у досліджуваній сировині обох видів.
Вступ. Флавоноїди та гідроксикоричні кислоти найпоширеніші френольні сполуки різної дії: покращують стан стінок капілярів, діють синергічно з аскорбіновою кислотою, мають протипроменеву, спазмолітичну, ранозагоювальну, протизапальну, гіпоглікеміч- ну, протипухлинну, бактерицидну, антирадикальну, сечогінну дію, позитивно впливають на моторику та секреторну фрункцію шлунково-кишкового тракту [1-4].

Малодосліджені рослини з досвідом застосування в народній медицині можуть стати новим джерелом

ISSN 2312-0967. Фармацевтичний часопис. 2020. № 4 
фенольних сполук. До таких рослин можна віднести представників родини Капустяні, роду Рижій - рижій посівний (Camelina sativa (L.) Crantz) і рижій дрібноплодий (Camelina microcarpa Andrz.), які поширені на території України та здавна застосовувалися як гіпоглікемічні, гіполіпідемічні, антиоксидантні засоби [5]. Хімічний склад цих представників досліджений недостатньо.

Тому метою роботи було дослідження складу фенольних сполук у траві та насінні рижію посівного та рижію дрібноплодого.

Матеріали і методи. Аналіз складу біологічно активних речовин фенольної природи здійснили в траві та насінні рижію посівного (сорт «Славутич») та рижію дрібноплодого. Зразки насіння для вирощування рослин надав Національний центр генетичних ресурсів рослин України (Інститут рослинництва імені В. Я. Юр'єва НААН України). Траву заготовляли на початку цвітіння (червень), а насіння - при достиганні плодів (липень) впродовж 2018-2019 рр. на території Запорізької області (м. Запоріжжя, с. Терсянка). Сировину сушили в затінку на відкритому повітрі, періодично перемішуючи. Для досліджень готували водно-спиртові витяжки, як екстрагент використовували $70 \%$ (об/об) етиловий спирт.

Для попередньої оцінки якісного складу витяжок застосовували якісні реакції та дослідження методом тонкошарової хроматографії (TШX) на пластинках «Sorbfil ПТСХ П-А UV-254» у системі розчинників н-бутанол - кислота оцтова льодяна - вода (4:1:2). Хроматограми переглядали у денному та УФ-світлі до і після обробки парами амоніаку.

Визначення якісного складу та кількісного вмісту окремих фенольних сполук виконували методом високоефективної рідинної хроматографрії (BEPX), застосовуючи рідинний хроматограср Agilent 1260 Infinity HPLC System, обладнаний дегазатором, бінарним насосом, автосамплером, термостатом колонки, діодно-матричним детектором. Умови хроматографрування: об'єм інжекції - 5 мкл; швидкість рухомої фрази - 1 мл/хв; температура термостату колонки - $35^{\circ} \mathrm{C}$; довжина хвилі детектування - 330 нм; колонка Zorbax SB-C18; 30 мм x 4,6 мм; 1,8 мкм. Градієнтне елюювання - елюент A: 0,1\% розчин трифтороцтової кислоти у воді, елюент Б: 0,1% розчин триортороцтової кислоти в ацетонітрилі. Режим хроматографрування:

$\begin{array}{ccc}\text { Час, хв } & \text { Елюент А, \% } & \text { Елюент Б, \% } \\ 0-5 & 95 & 5 \\ 5-35 & 95 \rightarrow 75 & 5 \rightarrow 25 \\ 35-40 & 75 & 25 \\ 40-45 & 75 \rightarrow 70 & 25 \rightarrow 30 \\ 45-50 & 70 \rightarrow 20 & 30 \rightarrow 80\end{array}$

Спектрофотометричні визначення виконували на спектрофотометрі ULAB108UV (Китай). Кількісне ви- значення вмісту похідних гідроксикоричних кислот визначали при довжині хвилі 525 нм згідно з методикою, наведеною в монографії «Кропиви листя» [6]. Визначення вмісту фрлавоноїдів проводили, вимірюючи абсорбцію комплексу фрлавоноїдів 3 алюмінію хлоридом, згідно з методикою [7]. Визначення вмісту суми поліфенольних сполук проводили при довжині хвилі 270 нм у перерахунку на галову кислоту згідно 3 методикою [8].

Статистичну обробку результатів дослідження виконували за допомогою програми STATISTICA 8 та пакета статистичних фрункцій програми Microsoft Excel [9].

Результати й обговорення. В результаті виконання ТШХ-досліджень встановлена наявність в траві та насінні всіх зразків рутину. В траві обох видів ідентиоріковано хлорогенову кислоту. Зразок хроматограми представлено на рисунку 1.

Методом BEPX в траві представників роду Camelina (L.) Crantz було визначено кількісний вміст рутину і хлорогенової кислоти (рис. 2-5). Результати BEPХ-дослідження сировини обох видів наведено в таблиці 1.

Вищий вміст рутину встановлено в насінні рижію дрібноплодого (0,361士0,001 \%), а вищий вміст хлорогенової кислоти - в траві рижію дрібноплодого $(0,279 \pm 0,004 \%)$.

Результати спектрофотометричного визначення вмісту фрлавоноїдів, похідних гідроксикоричних кислот і суми френольних сполук представлено у таблиці 2. Встановлено високий вміст фрлавоноїдів, похідних гідроксикоричних кислот і френольних

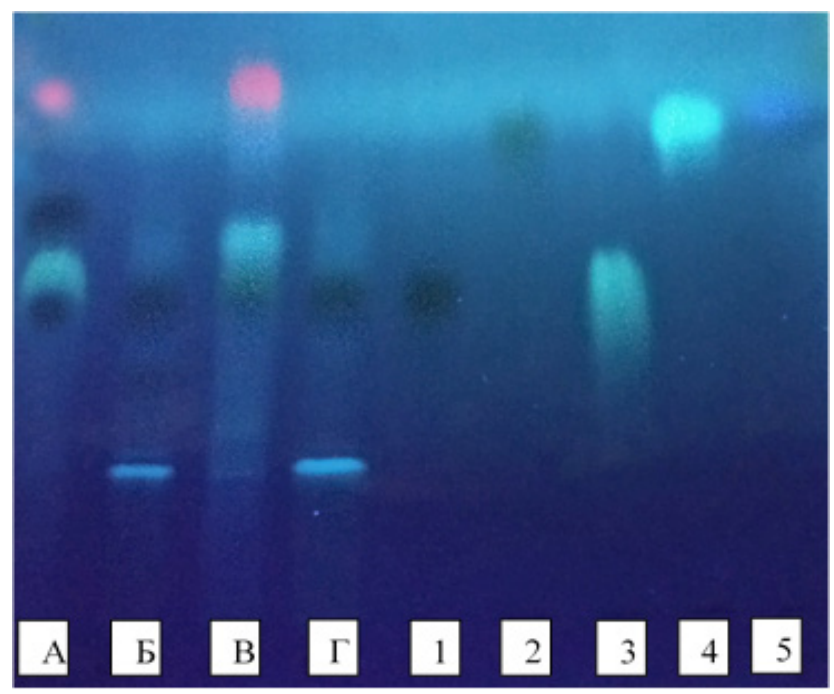

Рис. 1. Зразок ТШХ-досліджень, отриманий в умовах дослідження фенольних сполук. Треки випробовуваних розчинів: А - рижію посівного трави, Б - рижію посівного насіння, В - рижію дрібноплодого трави, Г - рижію дрібноплодого насіння. Треки стандартних розчинів: 1 - рутину, 2 - кверцетину, 3 - хлорогенової кислоти, 4 - кофейної кислоти, 5 - п-кумарової кислоти

ISSN 2312-0967. Pharmaceutical review. 2020. № 4 
Фітохімічні дослідження

Phytochemical researches

Таблиця 1

Результати хроматографічного визначення вмісту фенольних сполук у сировині видів Рижій

\begin{tabular}{|c|c|c|c|c|c|}
\hline \multirow{3}{*}{ Сполука } & \multirow{3}{*}{$\begin{array}{c}\text { Час } \\
\text { утримування, } \\
\text { хв }\end{array}$} & \multicolumn{4}{|c|}{ Вміст френольних сполук, \% } \\
\hline & & \multicolumn{2}{|c|}{ Рижій посівний } & \multicolumn{2}{|c|}{ Рижій дрібноплодий } \\
\hline & & трава & насіння & трава & насіння \\
\hline Хлорогенова кислота & 4,471 & $0,036 \pm 0,001$ & нд & $0,279 \pm 0,004$ & нд \\
\hline Рутин & 14,831 & $0,352 \pm 0,001$ & $0,344 \pm 0,003$ & $0,054 \pm 0,002$ & $0,361 \pm 0,001$ \\
\hline
\end{tabular}

Примітка: нд - не детектовано.

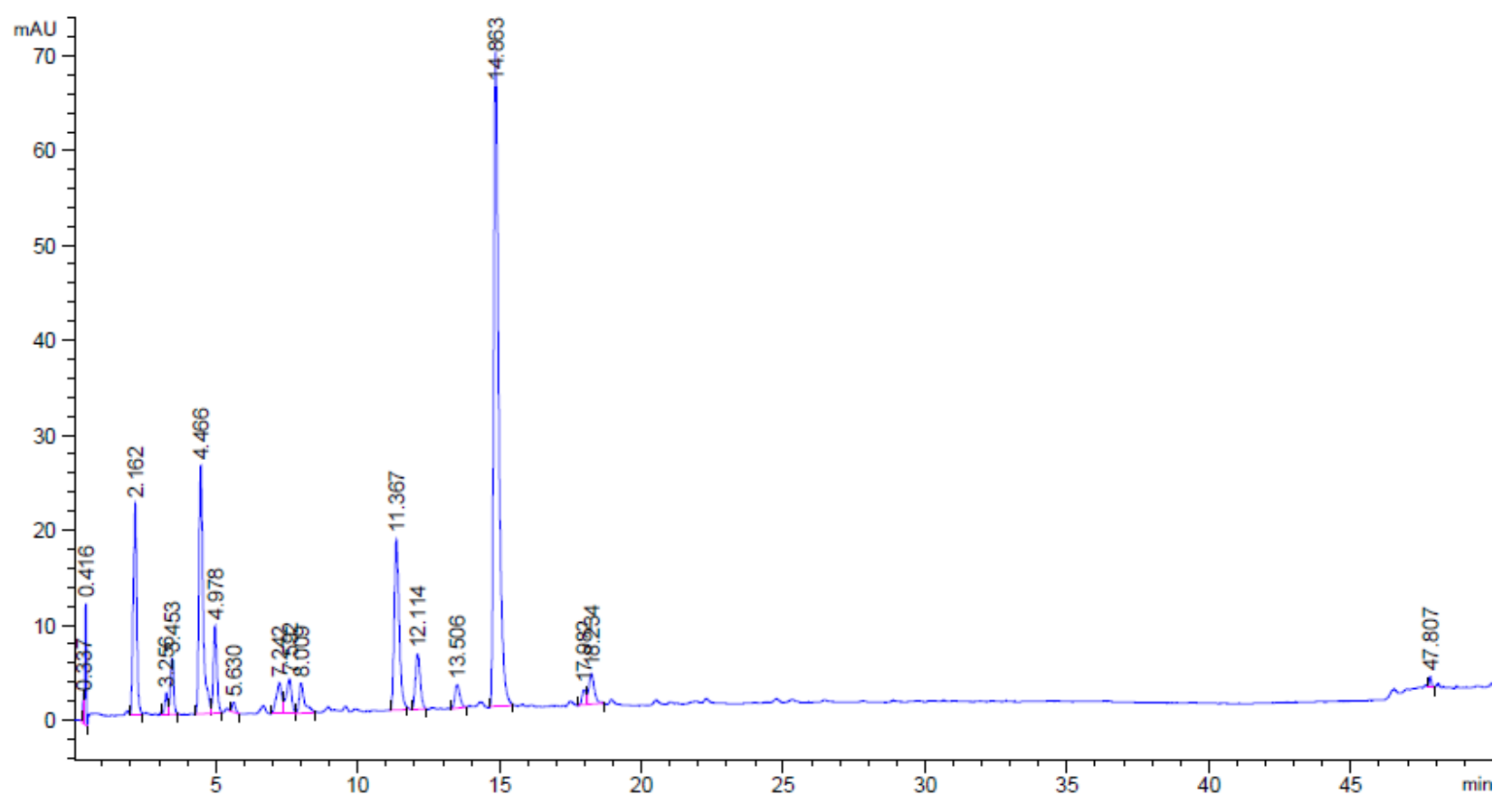

Рис. 2. ВЕРХ-хроматограма, отримана при дослідженні френольних сполук у траві рижію посівного.

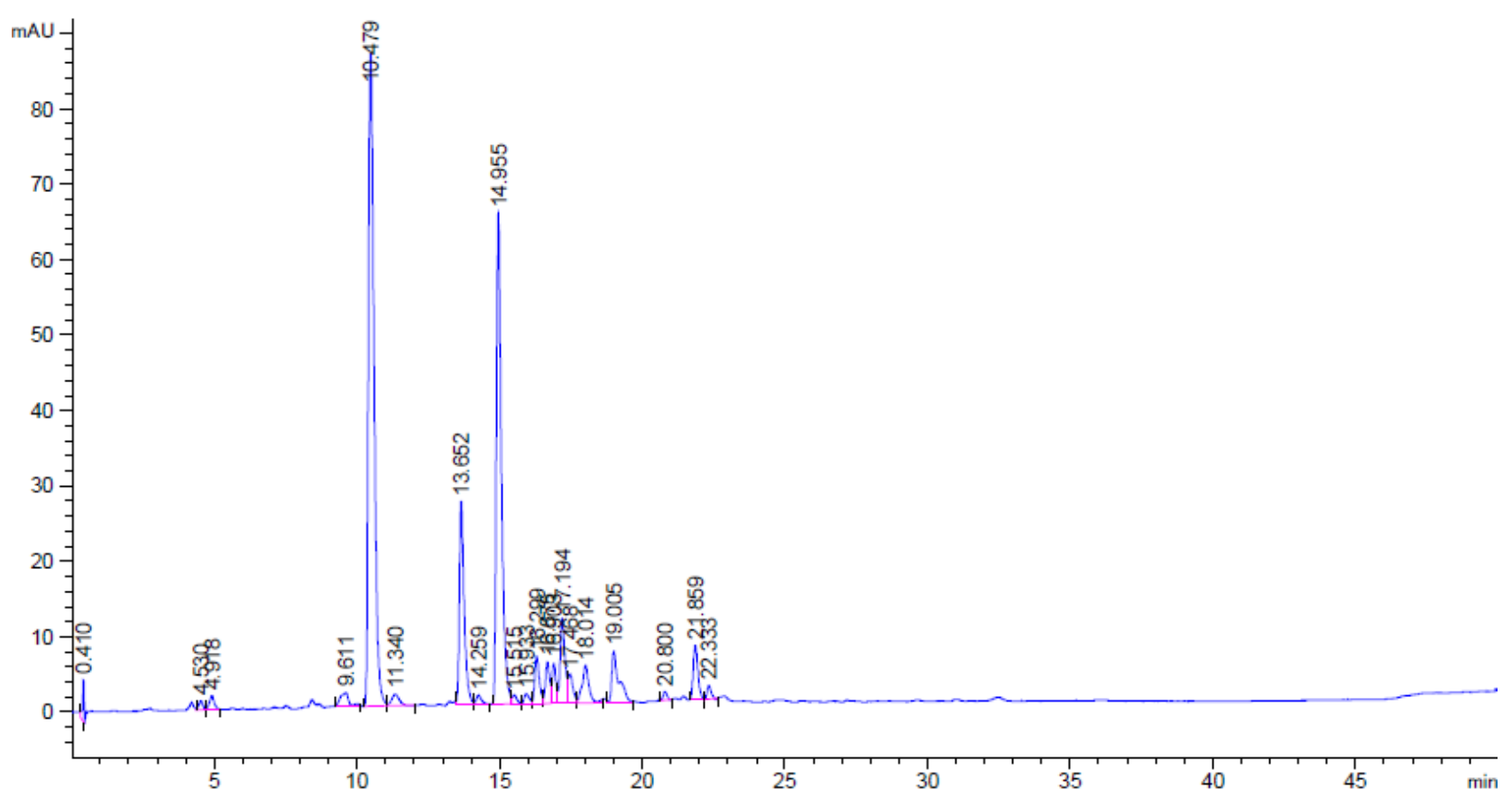

Рис. 3. ВЕРХ-хроматограма, отримана при дослідженні френольних сполук у насінні рижію посівного.

ISSN 2312-0967. Фармацевтичний часопис. 2020. № 4 


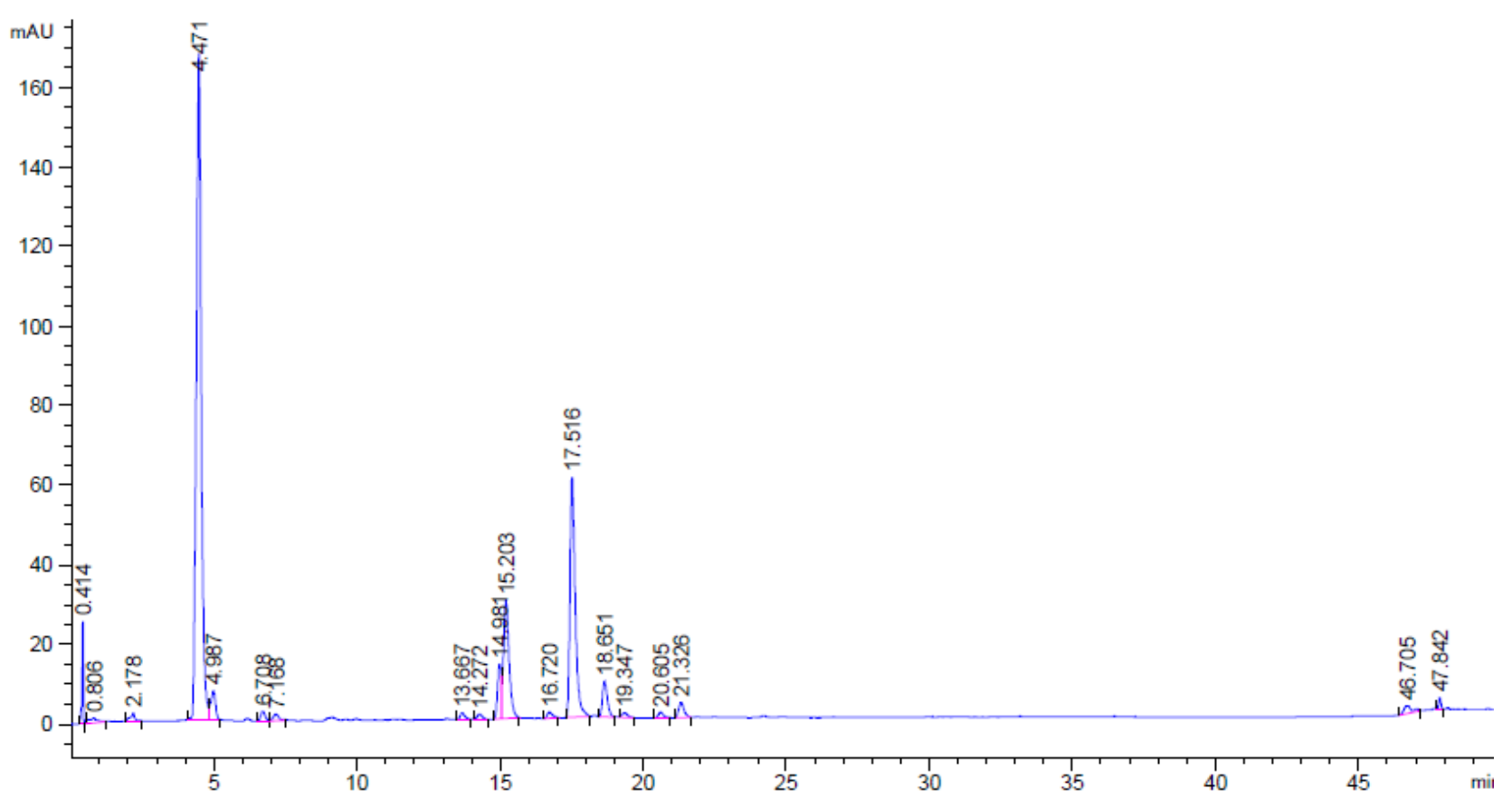

Рис. 4. ВEPX-хроматограма, отримана при дослідженні фенольних сполук у траві рижію дрібноплодого.

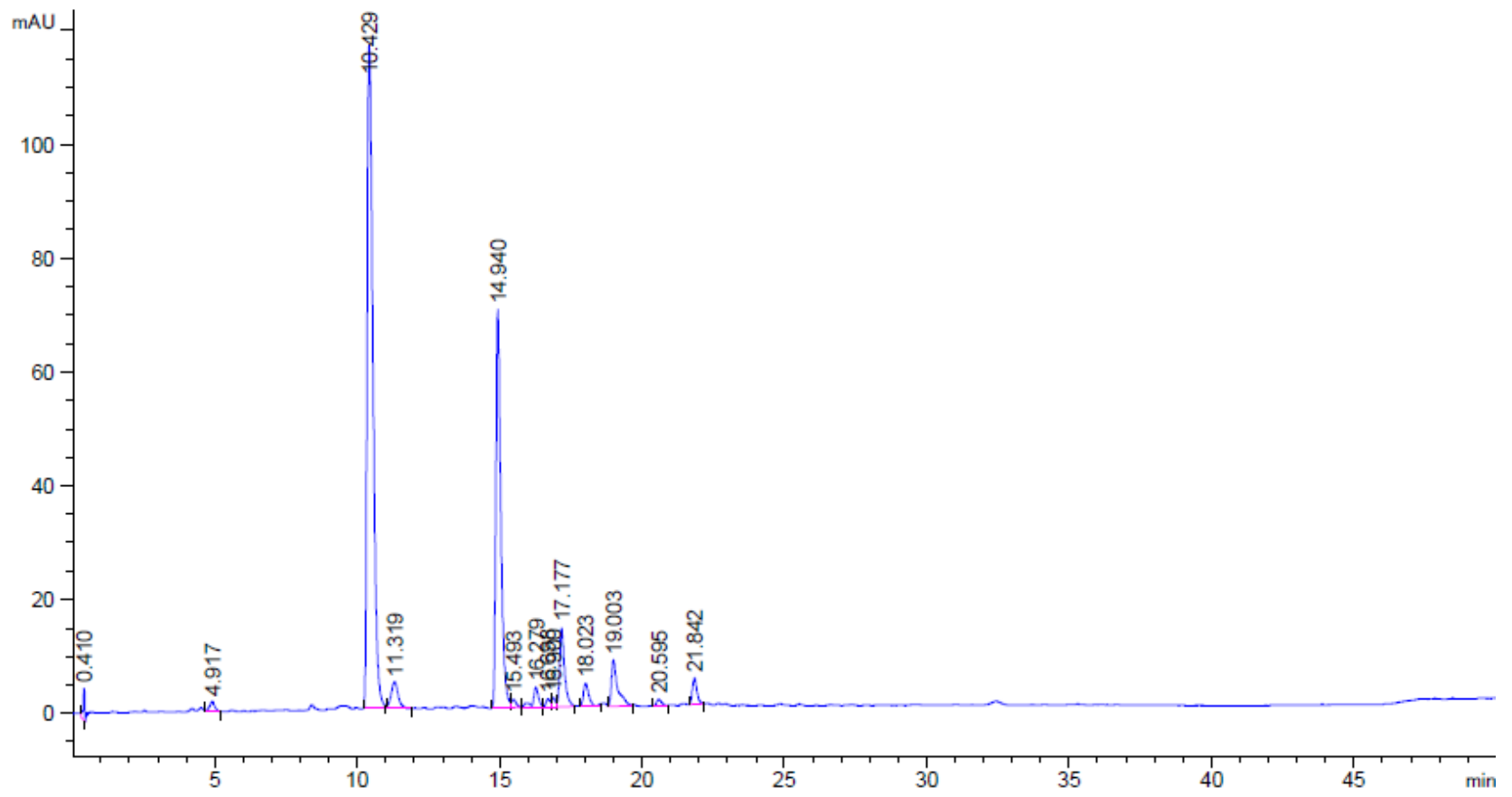

Рис. 5. ВЕРХ-хроматограма, отримана при дослідженні френольних сполук у насінні рижію дрібноплодого.

Таблиця 2

Результати спектрофотометричного визначення кількісного вмісту фенольних сполук у сировині видів Рижій

\begin{tabular}{|l|c|c|c|c|}
\hline \multirow{2}{*}{\multicolumn{2}{|c|}{ Групи БАР }} & \multicolumn{3}{|c|}{ Кількісний вміст у сухій сировині, \% } \\
\cline { 2 - 5 } & \multicolumn{2}{|c|}{ C. sativa (L.) Crantz } & \multicolumn{2}{c|}{ C. microcarpa Andrz. } \\
\cline { 2 - 5 } & трава & насіння & трава & насіння \\
\hline Флавоноїди & $1,17 \pm 0,08$ & $0,81 \pm 0,02$ & $0,97 \pm 0,02$ & $0,56 \pm 0,05$ \\
\hline Гідроксикоричні кислоти & $1,47 \pm 0,03$ & $0,90 \pm 0,04$ & $0,72 \pm 0,03$ & $0,70 \pm 0,02$ \\
\hline Полісреноли & $2,11 \pm 0,003$ & $1,26 \pm 0,02$ & $1,26 \pm 0,019$ & $1,17 \pm 0,03$ \\
\hline
\end{tabular}

ISSN 2312-0967. Pharmaceutical review. 2020. № 4 
сполук у траві рижію посівного сорту «Славутич».

Отримані результати схожі з результатами авторів [10], які вивчали вміст фенольних сполук у метанольних екстрактах із насіння рижію посівного, вирощеного та зібраного в Італії. Автори також ідентифрікували рутин у насінні рижію посівного та визначили кількісний вміст суми фрлавоноїдів, гідроксикоричних кислот та поліфенолів. Крім рутину, вони ідентифікували хлорогенову кислоту, кверцетин-3-О-глюкозид та кверцетин, тоді як вітчизняні зразки, які ми зібрали, не містили цих сполук.

Відомо, що в листі рижію посівного міститься кверцетин [11]. Ми не знайшли достовірні літературні дані щодо вмісту фенольних сполук у траві і насінні рижію дрібноплодого.

Відповідно до твердження авторів [12], такі френольні сполуки, як рутин та хлорогенова кислота можуть проявляти гіпоглікемічну активність. Також згідно 3 даними авторів [13], сировина, яку ми вивчали, за рахунок вмісту у своєму складі визначених фее- нольних сполук, ймовірніше, матиме антирадикальну та антиоксидантну активність.

Висновки. 1. Хроматографрічними методами було ідентисріковано та кількісно визначено вміст рутину та хлорогенової кислоти у траві і насінні рижію посівного (Camelina sativa (L.) Crantz) і рижію дрібноплодого (Camelina microcarpa Andrz.).

2. Спектрооротометричним методом було визначено загальний вміст фрлавоноїдів, гідроксикоричних кислот та поліфенолів. Вищим вміст перерахованих речовин є у проаналізованих зразках трави рижію посівного сорту «Славутич». Це вказує на перспективність подальшого дослідження i, можливо, майбутнього застосування Camelina sativa (L.) Crantz як джерела френольних сполук для розширення вітчизняної сировинної бази лікарських рослин і створення на їхній основі лікарських засобів.

Конфлікт інтересів: відсутній.

Conflicts of interest: authors have no conflict of interest to declare.

\section{INVESTIGATION OF PHENOLIC COMPOUNDS OF CAMELINA SATIVA (L.) CRANTZ AND CAMELINA MICROCARPA ANDRZ.}

\section{T. O. Tsykalo, S. D. Trzhetsynskyi}

\section{Zaporizhzhia State Medical University}

tetyanatsykalo@ukr.net

The aim of the work. To investigate the composition of phenolic compounds in the herb and seeds of Camelila Crantz species.

Materials and Methods. The herb and seeds of the Slavutych C. sativa (L.) Crantz and C. microcarpa Andrz. were used for the study. Water-alcohol extracts were prepared for the studies, and $70 \%$ ethyl alcohol was used as the extragent. For preliminary evaluation of the qualitative composition of extracts, a generally accepted qualitative reactions and thin layer chromatography (TLC) in a system of solvents n-butanol - glacial acetic acid - water (4: 1: 2) with reliable samples of phenolic compounds were used. Chromatograms were examined in daylight and UV light before and after treatment with ammonia vapor. Also, the determination of the qualitative composition and quantitative content of individual phenolic compounds was performed by the method of high performance liquid chromatography (HPLC). Quantitative determination of flavonoids, hydroxycinnamic acids and phenolic compounds was also performed with spectrophotometric method.

Results and Discussion. As a result of TLC, the presence of the substance of flavonoid nature (rutin) in herb and seeds of all samples was established. Hydroxycinnamic acid (chlorogenic acid) has also been identified in the grass of both species. In addition, the HPLC method confirmed the presence of these compounds of phenolic nature in the raw material of the genus Camelina (L.) Crantz. The highest content of rutin was found in the seeds of C. microcarpa Andrz. (0.361 \pm 0.001$) \%$, and the highest content of chlorogenic acid - in the herb of C. microcarpa Andrz. $(0.279 \pm 0.004) \%$. As a result of spectrophotometric study of the phenolic compounds content in these species raw materials, it was found that the highest content of flavonoids, derivants of hydroxycinnamic acids, and the content of phenolic compounds are characteristic of C. sativa (L.) Crantz herb, and it is $(1.17 \pm 0.08) \%,(1.47 \pm 0.03) \%$ and (2.11 \pm 0.003$) \%$, respectively.

Conclusions. The TLC method identified and HLCP method quantified the content of rutin and chlorogenic acid in grass and seeds of Camelina sativa (L.) Crantz and Camelina microcarpa Andrz. The total amount of flavonoids, hydroxycinnamic acids and polyphenols in the studied raw materials of both species was determined by spectrophotometric method.

Key words: Camelina sativa (L.) Crantz; Camelina microcarpa Andrz.; flavonoids; hydroxycinnamic acids; polyphenolic compounds; thin layer chromatography; high performance liquid chromatography.

ISSN 2312-0967. Фармацевтичний часопис. 2020. № 4 


\title{
ИССЛЕДОВАНИЕ ФЕНОЛЬНЫХ СОЕДИНЕНИЙ РЫЖИКА ПОСЕВНОГО (CAMELINA SATIVA (L.) CRANTZ) И РЫЖИКА МЕЛКОПЛОДНОГО (CAMELINA MICROCARPA ANDRZ.)
}

\author{
Т. А. Цыкало, С. Д. Тржецинский \\ Запорожский государственный медицинский университет \\ tetyanatsykalo@ukr.net
}

Цель работы. Исследовать состав фенольных соединений в траве и семенах видов рода Camelina (L.)

Материалы и методы. Для исследования использовали траву и семена рыжика посевного сорта Славутич и рыжика мелкоплодного. Для исследований готовили водно-спиртовые вытяжки, как экстрагент использовали 70 \% этиловый спирт. Для предварительной оценки качественного состава вытяжек использовали качественные реакции и ТСХ-исследование в системе растворителей н-бутанол - уксусная кислота ледяная - вода (4: 1: 2). Хроматограммы рассматривали при дневном и УФ-свете до и после обработки парами аммиака. Определение качественного состава и количественного содержания отдельных фенольных соединений выполняли методом ВЭЖХ. Количественное определение общего содержания фрлавоноидов, гидроксикоричных кислот и полифенолов выполняли спектрофотометрическим методом.

Результаты и обсуждение. В результате ТСХ-исследования установлено, что в траве и семенах всех образцов представителей рода Camelina (L.) Crantz присутствует рутин. В траве обоих видов идентифицировано хлорогеновую кислоту. Методом ВЭЖХ подтверждено наличие данных соединений и установлено, что содержание рутина выше в семенах рыжика мелкоплодного $(0,361 \pm 0,001) \%$, а хлорогеновой кислоты - в траве рыжика мелкоплодного $(0,279 \pm 0,004) \%$. В результате спектрофотометрического определения содержания фенольных соединений в сырье данных видов установлено, что большее содержание фрлавоноидов, производных гидроксикоричных кислот и общее содержание френольных соединений характерно для травы рыжика посевного и составляет $(1,17 \pm 0,08) \%$, $(1,47 \pm 0,03) \%$ и $(2,11 \pm 0,003) \%$ соответственно.

Выводы. Методом ТСХ идентифицировали и методом ВЭЖХ определили количественное содержание рутина и хлорогеновой кислоты в траве и семенах рыжика посевного (Camelina sativa (L.) Crantz) и рыжика мелкоплодного (Camelina microcarpa Andrz.). Спектрофотометрическим методом определили общую сумму фрлавоноидов, гидроксикоричных кислот и полифенолов в исследуемом сырье обоих видов.

Ключевые слова: рыжик посевной; рыжик мелкоплодный; фрлавоноиды; гидроксикоричные кислоты; полифенольные соединения; тонкослойная хроматография; высокоэффективная жидкостная хроматографрия.

\section{Список бібліографрічних посилань}

1. Experimental and chemometric study of antioxidant capacity of basil (Ocimum basilicum) extracts. B. Teofilović, N. Grujić-Letić, S. Goločorbin-Kon et al. Industrial Crops and Products. 2017. Vol. 100. P. 176182.

2. Flavonoids and other phenolic compounds from medicinal plants for pharmaceutical and medical aspects: An overview. Medicines. 2018. Vol. 5, No 3. P.93.

3. Ali Asgar M. Anti-diabetic potential of phenolic compounds: A review. International Journal of Food Properties. 2012. Vol. 16, No 1. P. 91-103.

4. Phenolic compounds: Functional properties, impact of processing and bioavailability. I. O. Minatel, C. V. Borges, M. I. Ferreira et al. Phenolic Compounds - Biological Activity. 2017. 24.

5. Рижій, сафрлор, кунжут. Стратегія виробництва олійної сировини в Україні (малопоширені культури) / І. А. Шевченко, О. І. Поляков, К. В. Ведмедєва, І. Б. Комарова. Запоріжжя : СТАТУС, 2017. - 40 с.

6. Державна Фармакопея України: в 3 т. / Державне підприємство «Український науковий фрармакопейний центр якості лікарських засобів». - 2-е вид. - Харків : Державне підприємство
«Український науковий фрармакопейний центр якості лікарських засобів». - 2014. - Т. 3. - 732 с.

7. Хохлова К. О. Розробка і валідація методики кількісного визначення суми фрлавоноїдів у настойці. Фармацевтичний часопис. 2014. № 1. С. 93-97.

8. Визначення кількісного вмісту френольних сполук у сировині дивини звичайної / Волошина А. А., Кисличенко В. С., Журавель І. О., Бурда Н. Є. Укр. журн. клін. та лаб. медицини. 2012. Т. 7, № 4. C. 202-203.

9. Державна Фармакопея України / ДП «Український науковий фрармакопейний центр якості лікарських засобів». 2-е вид. Доповнення 2. Харків : Державне підприємство «Український науковий фрармакопейний центр якості лікарських засобів», 2018. - 336 c.

10. Karamać M., Gai F., Peiretti P. G. Effect of the growth stage of false flax (Camelina sativa L.) on the phenolic compound content and antioxidant potential of the aerial part of the plant. Pol. J. Food Nutr. Sci. 2020. Vol. 70. No. 2. P. 189-198.

11. Leaf flavonoids of the cruciferous species, Camelina sativa, Crambe spp., Thlaspi arvense and several

ISSN 2312-0967. Pharmaceutical review. 2020. № 4 
other genera of the family Brassicaceae. J. Onyilagha, A. Bala, R. Hallett et al. Biochemical Systematics and Ecology. 2003. Vol. 31, No. 11. P. 1309-1322.

12. Chlorogenic acid and rutin play a major role in the in vivo anti-diabetic activity of Morus alba leaf extract on

\section{References}

1. Teofilović B, Grujić-Letić N, Goločorbin-Kon S, Stojanović S, Vastag G, \& Gadžurić S. Experimental and chemometric study of antioxidant capacity of basil (Ocimum basilicum) extracts. Industrial Crops and Products. 2017;100: 176-82. DOI:10.1016/j.indcrop.2017.02.039

2. Tungmunnithum $D$, Thongboonyou $A$, Pholboon $A$, Yangsabai A. Flavonoids and other phenolic compounds from medicinal plants for pharmaceutical and medical aspects: An overview. Medicines. 2018;3:93. DOI:10.3390/medicines5030093.

3. Ali Asgar M. Anti-diabetic potential of phenolic compounds: A review. International Journal of Food Properties. 2012;16(1): 91-103. DOI:10.1080/10942912.2 011.595864.

4. Minatel IO, Borges CV, Ferreira MI, Gomez HAG, Chen C-YO, Lima GPP. Phenolic compounds: Functional properties, impact of processing and bioavailability. Phenolic Compounds - Biological Activity. 2017:24. DOI:10.5772/66368.

5. Shevchenko IA, Poliakov OI, Vedmedieva KV, Komarova IB. Gold-of-pleasure, safflower, sesame. Strategy of production of oilseeds in Ukraine (rare crops). [Рижій, сафрлор, кунжут. Стратегія виробництва олійної сировини в Україні (малопоширені культури)] Zaporizhzhia: STATUS; 2017. Ukrainian.

6. The State Pharmacopoeia of Ukraine: in 3 vol. Kharkiv: Ukrainian Scientific Pharmacopoeia Center of Quality of Medicinal Products. Ed.2. Vol. 3. [Державна Фармакопея України: в 3 т.] Kharkiv: Ukrainian Scientific Pharmacopoeia Center of Quality of Medicinal Products. 2014. Ukrainian.

7. Khokhlova KO. [Development and validation of method of flavonoids in the determination of the amount tincture]. Farmatsevtychnyi chasopys. 2014;1: 93-7. Ukrainian. type II diabetic rats. A. Hunyadi, A. Martins, T.-J. Hsieh et al. PLOS ONE. 2012. Vol. 7, No 11, e50619.

13. Russo, R., \& Reggiani, R. Antioxidants in flour of the oilseed crop Camelina sativa (L.) Crantz. International Journal of Plant Biology. 2018. Vol. 9, No. 1. P. 39-42.

8. Voloshyna AA, Kyslychenko VS, Zhuravel IO, Burda NYe. [The study of quantitative content of phenolic compounds in the greater mullein plant material]. Ukraindkyi zhurnal klinichnoi ta laboratornoi medytsyny. 2012;7(4): 202-3. Ukrainian.

9. The State Pharmacopoeia of Ukraine: Ukrainian Scientific Pharmacopoeia Center of Quality of Medicinal Products. Ed.2, addition 2. [Державна Фармакопея України / ДП «Український науковий фрармакопейний центр якості лікарських засобів». 2-е вид. Доповнення 2.] Kharkiv: Ukrainian Scientific Pharmacopoeia Center of Quality of Medicinal Products. 2018; Ukrainian.

10. Karamać M, Gai F, Peiretti PG. Effect of the growth stage of false flax (Camelina sativa L.) on the phenolic compound content and antioxidant potential of the aerial part of the plant. Pol J Food Nutr Sci. 2020;70(2): 189-98. DOI:org/10.31883/pjf$\mathrm{ns} / 119719$

11. Onyilagha J, Bala A, Hallett R, Gruber M, Soroka J, Westcott N. Leaf flavonoids of the cruciferous species, Camelina sativa, Crambe spp., Thlaspi arvense and several other genera of the family Brassicaceae. Biochemical Systematics and Ecology. 2003;31(11): 1309-22. DOI:org/10.1016/S03051978(03)00074-7.

12. Hunyadi A, Martins A, Hsieh T-J, Seres A, Zupkó I. Chlorogenic acid and rutin play a major role in the in vivo anti-diabetic activity of Morus alba leaf extract on type II diabetic rats. PLoS ONE. 2012;7(11): e50619. DOI:10.1371/journal. pone.0050619.

13. Russo R, Reggiani R. Antioxidants in flour of the oilseed crop Camelina sativa (L.) Crantz. International Journal of Plant Biology, 2018;9(1): 39-42. DOI:org/10.4081/ pb.2018.7659.

\section{Відомості про авторів}

Цикало Т. О. - аспірант кафедри фрармакогнозії, фрармакології та ботаніки, Запорізький державний медичний університет, Запоріжжя, Україна. E-mail: tetyanatsykalo@ukr.net, ORCID 0000-0001-6976-8630

Тржецинський С. Д. - д. біол. наук, професор, завідувач кафредри фрармакогнозії, фрармакології та ботаніки, Запорізький державний медичний університет, Запоріжжя, Україна. E-mail: sersh_dm@ukr.net, ORCID 0000-00025219-3313

\section{Information about the authors}

Tsykalo T. O. - PhD-student of the Department of Pharmacognosy, Pharmacology and Botany, Zaporizhzhia State Medical University, Zaporizhzhia, Ukraine. E-mail: tetyanatsykalo@ukr.net, ORCID 0000-0001-6976-8630

Trzhetsynskyi S. D. - DSc (Biology), Professor, Head of the Department of Pharmacognosy, Pharmacology and Botany, Zaporizhzhia State Medical University, Zaporizhzhia, Ukraine. E-mail: sersh_dm@ukr.net, ORCID 0000-0002-5219-3313 